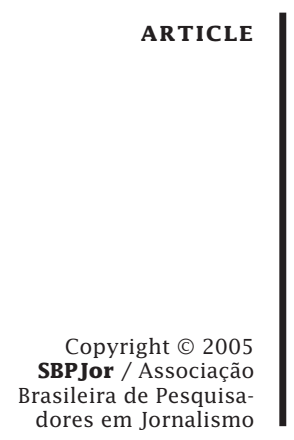

CRIME IN MEDIA

An interdisciplinary research

RONALDO HENN, CARMEN OLIVEIRA, MARIA PALMA WOLFF \& MARTA CONTE

Unisinos, Brazil

\begin{abstract}
This article analyses conceptual issues that present problems for interdisciplinary research - criminality and urban space; the transversal aspects of violence - developed by researchers from different fields: communications, psychology and social services. Highlighted in this work, above all, are questions related to the media and journalism; which constitute one of the axes of the proposal (media, growing juvenile component of criminality, drugs and social control) but are inevitably interconnected with the others due to the interdisciplinary force of the initiative. It is argued that the processes of report construction, the subject agenda and consumption of the news constitute complex semioses that involve other semiotic systems.
\end{abstract}

KEY-WORDS Journalism; criminality; semiosis.

This article starts with a presentation of some general considerations concerning the question of criminality from an interdisciplinary perspective, which lead later to specifying the questions related to the main focus of this paper, which is centered on the problems of the media and journalism. Criminality has been growing as a theme of major interest, and has gained visibility in the media and in the social image, as well as impacting on lifestyles and demanding actions by public authorities and communities to confront it. The concern with criminality can measured on the basis of a series of observations involving intricate processes that reflect the complexity of life in the city. There are three dimensions in this context that are of interest to this interdisciplinary research due to their being agents in the production of actions or transformations that involve urban criminality: journalistic processes of mediation, the organization of public policies, and the modes of subjectivity. 
One of the ways in which violence is most commonly expressed is through what is called diffuse criminality (SANTOS, 1989), which is to say, in the practice of common misdemeanors against persons or property, which will be the target for a criminalizing process and for punishment, formalizing its agent's link with the criminal courts and the penitentiary and socio-educational systems. Nevertheless, it is imperative that the subject is taken beyond just the strictly penal trial environment, its traditional treatment niche, to other levels of problem analysis, which implies not treating it as an autonomous product of certain agents, disconnected from social questions due to the infra-political or apolitical character that is attributed to it (MINAYO, 2003). In addition to this, there is the widening of the approach to identify movements that go counter to values that are intended to be hegemonies, as in for example, the importance given to repressive measures. This leads us to think of the mutations in the city from the perspective of these operations of transvaluation. (NIETZSCHE, 1999).

In the interdisciplinary project Criminality and urban space: the transversal aspects of violence, understanding is sought of these determinations starting from the penitentiary system, considering that the convicts were agents and victims at the same time, expressing the complexity of the theme. It was also of interest to understand the relationship that is established between prisons and urban space in terms of the problems involving mediation processes, social policies, drug usage and the growing juvenile component of criminality.

The reiterated choice of a interdisciplinary approach follows recent trends in social investigation. In the specific case of studies of criminality in various fields of study, the rule of floating meanings cannot to be ignored, as can be observed in the different study approaches involving Neurophysiology, Endocrinology, Genetics, Psychiatry, Anthropology, Sociology, Statistics, Economics, Psychoanalysis, and Communications, among other research areas. In particular in the XX century, in the polarization between the individual and collective nature of the determinants of criminal behavior, or between the theses concerning biological determinism and those defending social determinism, there have arisen multi-factorial theories, as well as the proposition of hybrid fields of investigation, as is the case with criminology.

In this way criminality is one of those subjects that remains outside the course of modern science, that is, avoids the tendency towards specialization, through which the division of a defined subject would permit the emergence of a specific autonomous discipline. While it is a 
hyper-complex system which is not amenable to approach in terms of cause and effect, criminality does not circumscribe a defined discourse, making its theorization delicate and paradoxical: to identify constants that are expressed, most frequently, in instability and in the multiplicity of disagreements (MAFFESOLI, 1987).

We are dealing, therefore, with a theme that exhibits some characteristics such as imprecision in measurements and uncertainty in predictions, resulting in a problem that can no longer be confronted by the specialized character of a single science. Nevertheless, even the proposal for bringing together all the understanding concerning criminality (as in the constitution of criminology and in the prospect of interdisciplinary investigation, as in our case) can still have as a starting point a branching vision of knowledge, in which the crossing between different understandings would be possible, but is pre-defined and even has a hierarchy, a multifaceted unity, but still with totalizing intentions. (DELEUZE, GUATTARI, 1997)

This being the case, in this investigation of criminality one seeks to overcome the limitations of disciplines, in favor of a dialogue between theoretical systems that, at the same time, breaks down the established disciplinary limits. (BRICEÑO-LÉON, 2002). More than this, the map of knowledge is taken as an immense rhizome, without a start and without an end, in which there can exist infinite possibilities of transit between areas, in unexpected ways, without the illusion of recovering a lost unity (GALLO, 1997). This investigation provoked new questions involving the production of meaning concerning criminality, having in view the organization of public and private spaces in the city and their links with the journalistic agenda concerning the subject.

\section{Discussion group}

The research used, among other instruments, a discussion group of prisoners in the semi-open system (by which prisoners are allowed to work outside the prison, returning there at night) of São Leopoldo, and semi-structured interviews with inmates of the prison in Novo Hamburgo, both being municipalities in the Metropolitan Region of Porto Alegre, the capital of the state of Rio Grande do Sul, Brazil. Due to its methodological characteristics, that is, being a qualitative, open instrument, directed by different actors with different interactions, group discussion provides for different transversal aspects in its analysis and favors adaptation of the approach to the complexity of the subject under study. 
In addition to this, group discussion, being a qualitative research methodology, suggests open planning as the investigator intervenes as a subject of the process. This way the "data produced in the process of investigation imprint themselves on the subject modifying him, and this modification makes him disposed to record the impression of - and mentally digest - new data and thus open an endless dialectic process" (IBÁÑEZ, 1992:263).

The same author defines three stages in the formation and organization of discussion groups: selection of the participants, implementation scheme, and interpretation and analysis. With respect to the selection of the participants, the option to apply this instrument to convicts was on the understanding that they represented the various facets of violence: at the same time violators and violated, infringers of rights and victims of the denial of rights. The participation of prisoners in semi-open and open systems was defined by the possibility of their movement and the possibility of their remaining without being escorted by prison guards during the carrying out of this research activity. It was understood that the holding of a group inside the prison would generate many limitations making the autonomy necessary for the application of this type of instrument infeasible.

The specifics of the prisoners and the conditions under which they should be observed were debated, given the degree to which they are located in a situation of total institutionalization. Some precautions were indicated: throughout the entire approach to the prisoners it was made clear that this was a research activity and was not to be confused with any form of counseling, and that it implied no changes whatsoever in the penal justice process. The listening role of the researchers was stressed as a buffer between prison life and life outside of the prison.

After this was defined and prior to the holding of the group, the project members went to the prison in São Leopoldo to invite the prisoners to participate. The approach was made through a brief explanation of the research work, finishing with a request for the prisoners' collaboration, making clear, principally, the limits to be placed on any possible expectations with respect to any intervention in their judicial situation.

Prisoners were selected on the basis of their manifesting an interest in taking part in the group and of their available hours, considering that some had outside employment and would only be available at a time later than that which had been established for the group to start. Thus the group had homogeneous characteristics, given by the judicial situation of its members, and at the same time was heterogeneous, as the selection 
of the participants was not linked to any other conditions such as their region of origin, type of crime, age etc. This equilibrium was necessary to ensure that there was no excessive homogenization of the discussion, nor that excessive heterogeneity made verbal communication impossible, making the discussion exclusive. It was intended to create an inclusive heterogeneity (IBÁÑEZ 1992:274).

After this had been defined, lists of the selected convicts were sent to the management of the prison and to the Criminal Court requesting that the prisoners be permitted to visit UNISINOS. The preparation of the group involved all of the research team, from the adoption of the specific methodology to the necessary delimitation of the subject of investigation. After much discussion it was decided that the subject to be addressed was the perception that the prisoners had of the criminalizing process of and of the punishment for the crime committed, given that this was a problem of interest to all of the focus areas of the project.

This set up, due to the characteristics of the team and the complexity of the subject presented, made it imperative to consider a situation in which knowledge could provide the experience of "transmutation or intercalation of disciplines, at the cost of their accessibility and participants" which also permits "the consideration of the crossover of specialties, the work on the interfaces, the crossing of boundaries, the migration of a concept from one field of knowledge to another, in addition to the actual unification of knowledge" (DOMINCUES, 2001:18).

The group met on the $16^{\text {th }}$ of September 2003 , on UNISINOS premises with 10 prisoners participating. These were received by the researchers, who showed them how the mirrored room worked, where those members of the team that were not coordinating the group would remain, and then they were offered refreshments.

These procedures of the "implementation scheme" were part of the group ecology, which sought to make possible the emergence of a more informal and relaxed attitude, facilitating the approach to the subjects. These aspects were particularly significant in this case, as they made it possible to mark the rupture with the prison environment, impregnated with tension, authoritarianism with different levels of censure, factors which would have been obstacles to any subjective expression.

After this period of relaxation, the objectives of the exercise were presented once more, the need for recording was explained and the role of the group discussion was especially reinforced, together with the impossibility of this having any influence on their punishments. The consent documents were reread with assistance, with an explanation of 
their purpose, and following this, the participants signed them with no restrictions.

Two researchers coordinated the group, with a research assistant remaining in the room, being responsible for recording the session. To get the discussion going, it was requested that all those in the group introduce themselves, and a suggestion was made for them to explain their offences, their sentences and types of punishment and some personal data that they considered important. The introductions were part of the "initial provocation" (IBAÑEZ, 1992), since by focusing on their time in prison the prisoners were already introducing questions relating to the process of incarceration. The coordinators tried to respect the direction of the discussion given by the prisoners. Only on a few occasions was it necessary to interrupt the group to ensure the equanimity of the participants. In this way, the coordinators proposed connections with the themes of interest to all of the researchers. No resistance to any of the themes introduced was observed. The discussions were lively and always included expressions of personal experience, both with respect to breaking the law or involvement with drugs as well as in the expression of feelings relating to family, society and prison, and, very significantly, in the expression of hopes and dreams for the future.

The group discussion lasted two hours. Before it finished, an evaluation was carried out by the participants and by the coordinators. The evaluations unanimously referred to positive aspects of the experience. On the coordinator's part, this was a possibility for viewing from the perspective of the actors deeply implicated in the problem being studied and, on the part of the convicts, it was the importance of being heard and valued as subjects, of having the opportunity for an experience so different from daily prison life, and also mentioned was the importance of the problems of the penal and prison system being discussed and recognized by society as a whole.

After transcription of the tapes that had been recorded, the process of analysis of the data obtained commenced. A first reading was made, extracting the principle meanings of the discourses, and from them, categories of analysis were proposed, which at that time were of a preliminary nature. After two further readings of the material now categorized, adjustments were made to the categories and subcategories, classifying the material accordingly. This process brought to the surface some elements and complications of interdisciplinary practice, bringing to mind that "the interdisciplinary perspective requires a dialogical effectiveness, open to awareness of what happens in other spheres 
of knowledge, even while maintaining a divergent position, as it is impossible to know everything, to cover all the angles in an investigation." (RODRIGUES, 2000:129)

The categories and sub divisions defined were:

1) Prison: conditions for serving time, justice, internal codes and family.

2) Processes of inclusion/exclusion: consumption, media, prejudice and resignation.

3) Drugs: inmate control, social function and dependency.

4) Public policy: work, access to social policies and governmental policies.

This categorization represents the continuous movement carried out by the researchers in their passage through the empirical space constituted by the discourse pronouncements and other expressions of the group - to the theoretical space, defined by the different accumulations originating from the disciplines and those already constructed in the process of the team's work. The proposal to share with the members of the group all the levels of this methodological construction allowed the members to include theoretical formulations from their fields, at the same time that they appropriated other knowledge through exposure to individual discursive trajectories in a transversal space.

\section{Media and agenda}

Through this instrument, complemented with semi-structured interviews, it is seen that the mediation processes of criminality are constituted, to a large degree, from the construction of reports on this subject in the press. From this perspective, the editorial agenda behaves as a contributor to the very perception that these communities develop concerning crime, in which the shifts of meaning and the critical flux in which meaning spaces are negotiated are given weight. The crime journalism agenda in which prejudice is reinforced, as shall be shown later, and against which the convict raises critical comments, mobilizes shifts in which resonances with the actual prejudices of the prisoners are established.

"Mediatization", in a broad sense, is a phenomenon that is already disseminated in contemporary society and has been assuming various forms proportional to its demolition of other media processes of the most complex hues. (SODRÉ, 2002) There is a behavioral choreography in which the force of the media is felt to the degree that the manipulation 
facilities of technological devices transform entire segments of culture into potential producers.

Violence, originating from various matrices and activated in specific configurations due to social inequalities, is incorporated in this process of "mediatization". It generates complex texts that are articulated in different semiotic systems. Just within the media there is a multiplicity of incorporations that range from meaning structures in which many narratives are constructed (television dramaturgy, television news, talk shows, reality shows, television auditoriums) to their classification as content and part of the news agenda. These structures migrate to the streets where they are hybridized with violent actions generating new systems of signs materialized in dialects, clothing, body art, gestures, and tribal rites.

More specifically, criminality to a large degree also organizes itself in these structures, a fact which suggests that it already, today, is widely "mediatized". The opposition to criminality expresses itself in the same way, from this perspective. In the most vulnerable segments of society, this "mediatization" can be transformed into an affirmative force involving denouncements and propositions of new dynamics.

The news, in particular, constitutes a media product through which current social reality is constructed. The constructionist perspective of journalism studies (TRAQUINA, 204; ALSINA, 1989) emphasizes that events only make sense when carried by news media. In addition to this, between the events and the transmission is a whole narrative, semiotic construction, subjected to a series of mediations. This dynamic results in the hypothesis that, in our society, it is the media -more specifically, the mass media - that produce social reality. This means that the process of reality construction would depend heavily upon journalistic production practice, a process that in another way could be called basic "mediatization".

However, the notion of the social construction of reality is not only linked to journalistic practice. This notion was inspired by a hypothesis formulated by Berger and Luckman (1991), for whom this construction was situated on the level of everyday life or, as suggests the semiotics proposed by C. S. Peirce, in an interpreting activity. If we consider the themes, with their respective settings and focuses, as signs that feed public discussion, these generate interpretations in which the meanings are not univocal, but mixed with other systems of signs which Peirce designates as collateral observation (PEIRCE, 1977) 
Amongst the innumerable definitions of signs given by Peirce, two stand out that, to some degree, synthesize the principles of semiose embedded in the concept of sign as a whole.

"A Sign or "Representamen", is something that, in some aspect, represents something to someone, directs itself to someone, that is, creates in the mind of that person an equivalent sign or maybe a more developed sign. This sign represents something, its Object - not in all of its aspects, but in reference to a kind of idea that I have at times called the foundation of the sign." (PEIRCE, 2.228)

"A sign is anything that represents another thing - its object - to any mind that can so interpret it. More explicitly, the Sign is something that appears in the place of its object, which does not appear for itself... In this way that the Sign is (...) the virtual 'apparition' or, figuratively speaking, emissary of the object and is capable of producing an effect in an intelligent being, effect that is called "Interpretant" of the sign - which is due, in some manner, to the object. It is in producing the "Interpretant" that the sign fulfills its own function - a function that makes it a Sign." (PEIRCE, MS 640)

These definitions reveal fundamental theoretical aspects of the Peircian sign theory. Firstly the sign is thought of in a triadic form and only exists as such on the basis of a relational process between the three dimensions involved: sign, object and "interpretant". Secondly if the "interpretant" is a new sign that is initiated in this process, and its generation is configured as potentially infinite, its functioning already has embedded its own semiosis which, in other terms, means the action of a sign. Thirdly the sign only exists due to a determination, that of its object, whose nature does not necessarily have to be that of some 'thing' constituted in the world, but something on the order of imagination or concept. And all sequences of "interpretants" will, in some way, deal with these original objects.

The advances that Peirce obsessively instituted in the conception of signs led to the understanding that semiosis, while it means the function, properly stated, of the sign (representation), also indicates the appearance of new signs inferred from the first (interpretation). The same process has a representative dimension and another interpretive one, which interlink in chains of infinite possibilities (HENN, 2002).

News production involves a complex process, which is understood, here, as semiosis. The reports form signs whose objects are the events that occur in everyday life. These are apt to produce "interpretants" of 
different shades that range from the formation of opinions concerning specific episodes to the generation of concrete actions in society.

The events that are the targets of the deciphering of journalists, present themselves as signs already. They are articulated by the sources (people or institutions to which journalists turn to obtain data for their material) and are imbued with various interests. Finally, in producing the news, the reporter uses an interpreting activity. It is a link in a chain that has built long before him (the event itself, its establishment in day-to-day life, the economic and political involvement, and, above all, the agenda, form links in the chain that precede the journalistic decodification).

Focusing on the report as a sign in the Peircian sense, however true this may be, its object, in the majority of cases, is already a sign. The report, in this sense, would be the resulting" interpretant" of a process. Between the report and the object that it represents exists a series of mediations, a flow of "interpretant" signs that will result in the publication and its respective repercussions. The object of the sign/report, in this sense, is already a sign or has passed through mediation of a socially produced sign by the sources.

M. R, Alsina (113-131) contends that the nexus between event/ source/report forms the central axis in the journalistic construction of reality. This is because the sources act as producers of news and often of artificial events that are transformed into news. In a society that is ever more directed toward the spectacular and media exposure, the great majority of social actions are planned with the intent of entering into the agenda of the press.

This construction of the news, which ends in the construction of an everyday reality, comes wrapped in distinct semiotic tones to make it attractive and competitive in the market. The semiosis is that which is being spoken of, ruled by previous codifications and which transforms itself either due to the need for survival of the languages themselves (which need to renew their informative content) or due to market impositions, when dealing with mass communications. In this way the news increasingly has its semiosis governed, to a large part, by the rules of the industry of the spectacular.

In the history of modern journalism, criminality has become the leader in a sector of the press that has consolidated itself as an industry, but has also converted itself into a sort of axis along which are delineated antagonistic discourses concerning social dynamics. This trend has become more acute over time and, recently, has been at the center of political debates in various examples of western societies. The press, 
to some degree, controls the discussion, promoting the inclusion of the theme in different fluxes and levels.

A populist and sensationalist focus is linked to the so called popular press that inaugurated, back at the end of the XIX century, the organization of the news as spectacle (HENN, 1992; ALBERT and TERROU, 1990). The press that considered as serious limited itself to covering stories of great repercussion and that involved macro-structural questions concerning public safety. The boundaries between one form and the other have become excessively porous given that the logic of entertainment permeates the structuring of journalistic information in a generalized manner.

Nevertheless, as a construction, there is a participation of the local communities in this process, as already indicated in the agenda setting hypothesis (McCOMBS; SHAW, 1972). These studies, as a whole, indicate that the influence of the media is not unilateral, but derives from the way consumers are organized on the basis of the environment in which they receive the message and the general context. In this sense, there tends to be a reaffirmation of the process-like character of the medium/receptor relationship.

In agenda setting, people build their knowledge of the world on the basis of what the media includes and excludes from its own content. While at the same time, the capacity for influence of the mass media on the knowledge of what is important and relevant varies according to the subjects treated. In other words, the mass media may not influence the receptors to the point of determining what they must do but, certainly, it establishes subjects with which society involves itself and thinks about for a period of time. And it is in the condition of being an interpreting activity that the consumption of this news constitutes complex semioses that involve other semiotic systems.

It is as a result of this that "mediatization" is postulated, not only as the incorporation of a collective agenda supplied by the journalistic media or even as a process of influence of its appeal to the senses. The term presupposes, equally, the transmutation of structures, of modes of social organization, of forms of living together and of the configuration of cultural products. The hegemonic media would be an outstanding source of these organization structures. However, it is argued that there are gaps in "semiotization" through which appropriations of media structures are reformatted to the point of causing a departure from their original meanings. On the other hand, selected portions of culture that form on the outskirts of the hegemonic system often develop products of such 
semiotic force that they end up invading and pressuring the structures of these media.

The world of semiosis, which is the semiosphere', delimits a complex and heterogeneous structure that continuously interacts with the space outside it. In this dynamic, culture not only constitutes its internal organization but also its external degeneration, which suggests that the culture is continuously overflowing its territory. Violence as a cultural phenomenon is made exponential by media processes, inhabits the semiosphere, installing itself in its own structure: it generates semioses.

Prysthon (2004) detects these movements in his research concerning the negotiation between youth and the media on the outskirts of the city of Recife. Faced with the predominance of texts appealing to juveniles in the media environment, in which consumption has primacy, the author noticed a curious situation: the degree in which consumerist images and slogans bombard the youth to the point that they themselves enter into the category of disposable goods; they normally appear as passive, apathetic and depoliticized. However the author reports that sectors of the youth produced some more radical changes in contemporary culture "from cultural movements, particularly in music, originating in the outskirts, the youths of the less favored classes have come to have a voice in a type of political participation completely distinct to that of the $60 \mathrm{~s}$, for example. This aspect can easily be found in Hip-hop. The appearance of texts of this nature and the appropriation of meaning in relation to what is presented in the conventional press can provide important indicators to new ways of confronting criminality.

There is, in this perspective, a proposition of a field of media and interdisciplinary investigation in which one can consider the multiple "intersemioses" of these processes as ruptures in the dichotomy production/reception, to the extent that much more than poles configure levels that intercross in all the communication movements. In some way, the first analysts of media processes, such as Walter Benjamin, Edgar Morin and Macluhan, predicted this potentiality. Regardless of the different matrices of their formulations, there is in these authors the proposition that, with the emergence of the media, creation is transformed into production or translation and all, potentially, are producers.

To see how this potentiality (that is already a property of signs, principally in their iconic vagueness, in the sense of C. S. Peirce) is put into operation, generating texts that provoke noise in the hegemonic media, constitutes a useful question connected with the agenda problem. This is because in the area of criminality, media texts are, according 
to the general rule, marked by socially excluding concepts (HENN and OLIVEIRA, 2004), through which the most vulnerable populations appear stigmatized, amongst other things, as the focus of the problem. The logic governing texts involving criminality corresponds to a view of public security as protection of the middle classes, or of the perception of the event in its spectacular and dramatic dimension. Meanwhile, the major victims, in numerical terms, who comprise the more vulnerable segments of the population, appear in out-of-context reports, do not have faces, identities or demands (HENN and OLIVERA, 2004). It is noted, however, that other texts emerge in these communities, both in the appropriation of the meanings that are made of the hegemonic media, as well as in the effective production of confrontational cultural/media products.

\section{Transmutations}

At the time of the interviews with the prisoners of Novo Hamburgo (July 2004), a rumor-laden case had made the pages of the newspapers in the metropolitan region of Porto Alegre with a high profile and a long stay on the agenda (for three weeks the subject headed the crime pages with repeated teasers on the front page). This referred to the murder of a journalist, whose carbonized body was found in a burned-out car, a crime supposedly ordered by her husband. The ingredients for repercussion were all present in this case: an upper middle class couple, apparently happy but with suspicions of betrayal and financial problems. On the intensity of the report, one of the prisoners formulated the following consideration:

Due to her being a journalist and him a businessman. You can be sure. You see, you went there, robbed the store, You robbed, you were arrested, it doesn't have repercussions, none, the paper can put a small note in the corner - it was so, so and so, but if there people with more financial power, with more ability, with more knowledge. Knowledge of people, influence, this makes it more public, the reports that come out in the paper are much bigger.

This observation, reiterated in other comments, reveals an interesting internalization of the codes of reportability from a critical perspective in relation to their possible exclusion strategies. It deals with the perception of someone who produced criminal actions that could have been reported, but whose visibility will depends on criteria instituted by the journalistic machinery itself. 
While in the group discussion held with the prisoners from São Leopoldo (September 2003), the operation of these codes working from specific categorization as a reinforcement of prejudices, constituted a subject for comments.

Today they were saying on TV, a father raped his daughter... A prisoner left his jail and raped... Then they say "ah! He is jailed". Then the other Joe is caught, thus he is a rapist too, he has the same capacity.

...if you, sir, was looking at one of those reports. "bah, he assaulted, clonked the woman on the head, tied up the man and shot him in the leg..." Then tomorrow or later I arrive at your house, sir, having a business of some kind there that caused you to have visited the jail and to have seen me there... "Oh, mate, got any work you need doing..." You could be needing it, but will you risk it, letting the guy in there..."

The perception of the reinforcement of prejudices on the basis of identification with a rapist is a form of dialogue between the codes of journalism and the internal codes of the prison system itself, with shifting of affinities. Rape is a crime that has been historically condemned by the prisoners themselves and any suspected rapist that arrives in a cell suffers violent reprisals. In other words, the prisoner himself that perceived the incongruence in the visibility of the suspects and in the association of barbarous crimes with any other type of crime acts, in these cases, in consonance with the righteous discourse that is the tone of the late afternoon crime programs on Brazilian television.

This multiple constitution of meanings in the intercrossing of the journalistic agenda on criminality and other semiotic systems in a complex process of "mediatization" forms one of the nuclei of the research that is being announced here. This interpretive activity is already used in its own production of news through a network of mediations that interpenetrate various systemic connections, highlighting the relationship of journalists with their sources. The object of the report is considered a sign, given that it is on the order of signs or passes through the mediation of signs that is socially produced by the sources (HENN, 1996).

In the case of reports about crimes, the dependency on police sources reiterates certain decisions of inclusion, exclusion and hierarchy formation through which stereotypes are reinforced. This situation gets worse, due to the rarity of events being portrayed that are not constructed based on the establishment of a contextual nexus which reveals, in this area, journalism of low investigative intent and tied to the logic of crystallized 
reporting. The great problem is that the most important source in this area is still the reports of the incidents from the police stations, produced in a precarious manner that often induce errors and even precipitous prejudgments ${ }^{2}$.

In another paper (HENN, 2000), it is postulated that the everyday world is defined or even constructed by the journalistic system, in the sense that society occupies itself every day with that which the newspapers explore in their facts and subject matter. In organizing the events and establishing angles, journalism appropriates events returning them to the medium now with their transmutations. This power of journalism, however, is rendered relative by, among other things, its dependency on specific source structures and by its own interpreting activity that it uses in the reception of material and with which it is inevitably connected.

\section{NOTES}

1 Lotman (1999) defined the space in which culture materializes as the semiosphere, which functions as a dynamic and open system, but is subject to fluctuations of various types. The relationship of the system with what is outside it and the tension between the static and dynamic are the fundamental questions concerning this semiotic space.

2 In a survey made over three months in 2001 of the newspapers Zero Hora and Correio do Povo, in Porto Alegre, of all the reports on crime in these publications, 50 per cent of the source materials were exclusively the police reports (HENN e OLIVEIRA, 2004).

\section{BIBLIOGRAPHY}

ALBERT, P; TERROU, F. História da imprensa. São Paulo: Martins Fontes, 1990.

ALSINA,M.R. La Construcción de la Notícia. Barcelona: Paidós, 1989.

BARMAN, Zigmund. Globalização: conseqüências humanas. Rio de Janeiro, Jorge Zahar Editores, 1998.

BAUMAN, Zygmund. Comunidade. Rio de Janeiro, Jorge Zahar Editor. 2003. 
BERGER, R.P.; LUCKMANN,T.. A Construção Social da Realidade. Petrópolis: Vozes, 1991.

DIÓGENES, Glória. Cartografias da Cultura e da Violência. São Paulo: Annablume, 1998.

DOMINGUES, Ivan. Conhecimento e transdisciplinaridade. Editora UFMG; IEAT. Belo Horizonte, 2001.

FONTCUBERTA, M. La Noticia, Pistas Para Perceber el Mundo. Barcelona: Paidós, 1993.

FREIRE COSTA, Jurandir. Violência e Psicanálise. Rio de Janeiro: Graal, 1986.

GALLO, Sílvio. Conhecimento, transversalidade e educacão: para além da interdisciplinariedade. Impulso. Vol. 10, no. 21. Piracicaba: Ed. Unimep, 1997.

GUATTARI, F.; ROLNIK, S. Micropolítica. Petrópolis: Vozes, 1988.

HENN, Ronaldo; OLIVEIRA, Carmen, Hiperdimensionamento do noticiário sobre criminalidade juvenil. Salvador: II SBPjor, 2004

HENN, Ronaldo. Os fluxos da notícia. São Leopoldo, Ed. Unisinos, 2003.

"Park Row: a gênese do jornalismo moderno", in BERGER, Christa (org.), Jornalismo no Cinema. Porto Alegre: Editora da UFRGS, 2003. Apontamentos para uma semiótica sistêmica. NP 15, XXIII Intercom. Campo Grande, 2001.

Pauta e notícia, uma abordagem semiótica. Canoas: Ulbra, 1996.

IBANEZ, Jesús. Más allá de la sociología. El grupo de discusión: Técnica y crítica. Siglo Veintiuno Editores, sa. Madrid, 1992.

LOTMAN, Yuri, Cultura y explosión. Lo previsible e lo imprevisible em Iso procesos de cambio social. Barcelona: Gedisa, 1999

McCOMBS, M. E., SHAW, D. L.. "The agenda-setting functions of the mass media". Public Opinion Quartellty, n. 36, 1972.

MAFFESOLI, Michel. Dinâmica da Violência. São Paulo: Editora Revista dos Tribunais, 1987.

MARCONDES FILHO, Ciro. O Capital da Notícia. São Paulo: Ática, 1989.

MINAYO, Maria Cecília de Souza (org). Violência sob o olhar da saúde. Rio de Janeiro: Ed. FIOCRUZ, 2003.

(org). Pesquisa Social: teoria, método e criatividade. 9a . Ed. Petrópolis: Vozes, 1998.

MOUILlAUD, M. O Jornal, da Forma ao Sentido. Brasília: Paralelo 15, 1997.

NIETZSCHE, Friedrich, Além do bem e do mal. São Paulo: Companhia das Letras, 1999. 
OLIVEIRA, Carmen S. de. Report Um pacto pela juventude de São Leopoldo, 2003.

PEIRCE, Charles Sander. Collected Papers. USA: Harvard Press.

Semiótica. São Paulo: Perspectiva, 1977.

PRYSTHON, Ângela. Negociações na periferia: mídia e jovens no Recife. Salvador: Intercom, 2002.

RODRIGUES, Maria Lúcia. "Caminhos da transdisciplinaridade: fugindo às injunções lineares”, in Serviço social e sociedade. São Paulo: Cortez, Ano XXI, nº 64, 2000.

SANTOS, José Vicente Tavares dos. "Violências, América Latina: a disseminação de formas de violência e os estudos sobre conflitualidades". Sociologias. Porto Alegre: UFRGS. IFCH. Ano 4, no. 8, jul/dez, 2002.

SODRÉ, Muniz. Antropológica do espelho. Uma teoria da comunicação linear e em rede. Petrópolis: Vozes, 2002.

TRAQUINA, Nelson. Teorias do Jornalismo. Volume 1. Porque as notícias são como são. Florianópolis: Editora Insular, 2004.

O estudo do jornalismo no século XX. São Leopoldo: Unisinos, 2001. (org) Jornalismo, Questões, Teorias e “Estórias”. Lisboa: Veja, 1993.

Ronaldo Henn is a doctor and lecturer in the Post Graduate Program in Communication Science at Unisinos, Brazil; Carmen Oliveira and Marta Conte are doctors and lecturers in the Psychology course at Unisinos; Maria Palma Wolff is a doctor and lecturer in the Social Services course at Unisinos. All these researchers comprise the Interdisciplinary Study Group on Violence at Unisinos. 
